\begin{tabular}{ll}
\hline 究 \\
\hline
\end{tabular}

\title{
鼻副鼻腔粘膜における複合糖質
}

一正常, 腫煬について一

\author{
金 春順・大石 公子・鵜飼幸太郎 \\ 坂倉 康夫・矢谷 隆一*
}

\section{Glycoconjugates in Normal Nasal and Maxillary Mucosa and Neoplasms}

\author{
Jin Chun Shun, Kimiko Ohishi, Kotaro Ukai, \\ Yasuo Sakakura and Ryuichi Yatani \\ (Mie University)
}

Glycoconjugates in the nasal and maxillary mucosa of normal controls and of patients with inverted papilloma, epithelial dysplasia and carcinoma were studied by the lectins-HRP staining method. Four kinds of lectin were used: WGA, PNA, UEA-1, and RCA.

1. Control nasal epithelium reacted to WGA and UEA-1. Some sugar residues stained with WGA, PNA, UEA-1 and RCA were detected in various amounts in the goblet cells and mucous cells of the subepithelial glands. Serous cells in the glands were stained by UEA-1.

2. There was a similarity of WGA and UEA-1 staining in inverted papilloma, epithelial dysplasia, and control epithelium.

3. Adenoid cystic carcinoma was not stained by any of the lectins. According to cellular differentiation, Squamous cell carcinoma showed various staining patterns depending on the degree of differentiation.

4. Lectin staining may be a useful marker in the early diagnosis and cell differentiation of nasal and maxillary carcinomas.

Key words: glycoconjugates, lectin, naso-maxillary mucosa, inverted papilloma, squamous cell carcinoma 


\section{はじめに}

近年, 細胞の分化, 加齢, 変性, 悪性化等の 過程で，細胞や組織を構成する複合糖質の糖鎖 構造の変化が注目されている。こうした糖鎖の 変化は，特定の糖構造と特異的に絬合する糖結 合性蛋白質であるレクチンを用いて組織練胞化 学的に解析することができる ${ }^{11}$. 今回，われわ れは糖絬合特異性の異なる 4 種類のレクチンを 用いて, 正常ヒトの鼻副鼻腔粘膜を対照として 鼻腔，上顎洞腫瘍における複合糖質の分布とそ の変化を Horseradish Peroxidase (HRP) 標 識法により光顕的に比較検討し，さらに悪性病 変に対する本染色の有用性に検討を加えた。

\section{材料および方法}

1. 試料：正常下鼻甲介粘膜は喉頭病変や中 耳炎症例などから鼻疾患のない症例を選び患者 の了解をえて全身麻酔下手術時に採取した 6 例 と, 明らかな鼻疾患の既往のない剖検屍体から 採取した肉眼的に正常と思われるむの 4 例を用 いた。正常上顎洞粘膜は剖検屍体から採取した 10例を用いた。鼻腔, 副鼻腔腫瘍は手術摘出標 本28例を用いた。すなわち, 乳頭腫 (inverted papilloma） 4 例, 異形成（dysplasia） 3 例, 腺様囊胞癌 4 例, 扁平上皮癌17例である.

2.レクチン：糖特異性の判明している wheat germ agglutinin (WGA), Peanut agglutinin (PNA), Ulex europeus agglutinin (UEA-1), Ricinus communis agglu$\operatorname{tinin}(\mathrm{RCA})$ の 4 種類の HRP 標識レクチン （EY-laboratories 社製）を用いた（表 1 ）.

3. 染色：各種固定液（カルノア液, $10 \%$ 中
性ホルマリン液，10\%ホルマリン液）によるレ クチン結合様式の差異の有無をあらかじめ検討 した結果, 原則として中性ホルマリンにて固定 した. 固定試料によりパラフィン包埋薄切切片 （厚さ $4 \mu \mathrm{m}$ ）を作製し，脱パラフィン後 HRP 標識レクチンを用い染色した。まず， $0.3 \%$ $\mathrm{H}_{2} \mathrm{O}_{2}$ 一メタノールで内因性ペルオキシダーゼ を抑制したのち，10\% Bovine serum albumin-PBS でレクチンの非特異的反応を防ぐた めの処理を行った. その後, $50 \mu \mathrm{g} / \mathrm{ml}$ の HRP 標識レクチンを室温にて30分反応させ，Dulbecco's PBS で洗浄した. ついで，3,3'-diaminbenzidine (DAB) にて発色させたのち, 水洗した。 その後, メチルグリーンあるいはへ マトキシリンにて，核染色，水洗，脱水及び封 入した．対照として，それぞれのハプテン糖を 各0.2Mの濃度にて処理したレクチンを使用し， それらの特異性を見るもの之，内因性ペルオキ シダーゼをブロックしたのち, レクチンを反応 させず DAB 反応を行ったものを同時に染色 して比較検討した。

4. 定量的観察法：検鏡は 200 倍率で行い, 各標本每で全視野の杯細胞之腺細胞における各 レクチン反忘の陽性率を求めた.

5. 扁平上皮癌の分化度 : 扁平上皮癌の分化 度は光学顕微鏡的病理組織学的に著者の 1 人

（R Y）が判定した。

\section{結果}

各個体間, 各種固定液による差異は, レクチ ン結合パターンに関する限りほとんど涊められ なかった。

表 I 本研究で用いたレクチン

\begin{tabular}{c|l|c}
\hline $\begin{array}{c}\text { レクチン } \\
\text { (略称) }\end{array}$ & \multicolumn{1}{|c|}{ 小 結 合 糖 } & \multicolumn{1}{c}{ 結合阻害に用いる糖 } \\
\hline WGA & $\begin{array}{l}\text { N-アセチル-D-グルコサミン } \\
\text { シアル酸 }\end{array}$ & N-アセチル-D-グルコサミン \\
PNA & $\begin{array}{l}\text { D-ガラクトース } \\
\text { N-アセチル-D-ガラクトサミン }\end{array}$ & ラクトース \\
UEA-1 & L-フコース & L-フコース \\
RCA & D-ガラクトース & D-ガラクトース
\end{tabular}




\section{1. 対照実験}

対照実験として特異的阻害糖の添加と内因性 ペルオキシダーゼを阻害した後 DAB 反応のみ を行うといずれの場合にも陽性反応は認められ なかった。

2. 正常下鼻甲介粘膜

(1)WGA：上皮層はびまん性に軽染し，杯細 胞の約 $25 \%$ が反応陽性を示した. 鼻腺の粘液細 胞は約20〜50\%に反応陽性であった。

(2)PNA：約 25〜 50\%の杯細胞と粘液細胞に 反応産物が観察された。しかし, 杯細胞以外の 上皮細胞には染色性がみられなかった。

(3)UEA-1：上皮層にびまん性反応を認め た. 大多数の杯細胞と粘液細胞にも強い反応を 認めたほか，血管内皮と基底膜，また若干の漿 液細胞にあ陽性反応を観察した（図 1 ）.

(4)RCA：約半数の杯細胞以外に上皮細胞の 反応を認めなかった. 固有層の鼻腺では, 多数 の粘液細胞に陽性反応が認められ, 固有層も全 体に軽染された。

\section{3 . 正常上顎洞粘膜}

上顎洞粘膜は鼻粘膜に比し，上皮下固有層の 分泌腺は少数だが, 杯細胞が比較的多い.

(1)WGA：約 $25 \% の$ 杯細胞に陽性反忘を認 め, 少数の腺細胞が染色性を示した.

(2)PNA : 約半数の杯細胞と若干の腺細胞に 反応が観察された（図 2 ).

(3)UEA-1：多数の杯細胞および腺細胞に強 い陽性反応があり, 粘膜表面の粘液と血管内皮 にも反㐫が陽性であった（図 3 ).

(4)RCA：多数の杯細胞と約 $25 \%$ の粘液細胞 が反応陽性であった（表 2 ）.

\section{4. 異形成}

異形成上皮ではレクチンの染色様式は癌と異 なり, 細胞質あるいは細胞膜に WGA, UEA-1 の反応が陽性であったが, PNA, RCA 反応 はまったく陰性であった（表 3 ）.

\section{5 . 鼻副鼻腔の乳頭腫}

乳頭腫の上皮層では WGA と UEA-1 で上 皮の細胞膜が反応陽性であったが, PNA およ
び RCA の結合性は陰性であった（図 4).

6. 副鼻腔の腺様囊胞癌

4 例ともいずれのレクチンにもまったく反応 を示さなかった。

7. 副鼻腔の扁平上皮癌

扁平上皮癌では分化によるレクチンの染色性 の相異が認められた。

(1)高分化型：高分化型では， 6 例中 5 例（83 \%) が図 5 および図 6 に示したように癌細胞の 細胞膜, 少数の細胞質の周辺部及び細胞核に WGA，PNA，RCA 陽性反応を認めたが, UEA-1 反応は陰性であった. その中であ, PNA の反応が最も高度であった。しかし， 1 例 $(17 \%)$ はGA と UEA-1 に反応陽性で あった。

(2)中分化型：この型では 7 例中 4 例 $(57 \%)$ は高分化扁平上皮癌とほぼ同じ染色性であった がほほかの 3 例 (43\%) はUEA-1 にのみ反 応をみとめ, 他のレクチンに対しては反応性を 示さなかった。

(3)低分化型：低分化扁平上皮癌の 4 例中 3 例 （75\%）はいずれのレクチンにも反応陰性であ ったが，1例（25\%）は UEA-1 のみ反応陽性 であった。

\section{考按}

組織や細胞には様々な複合糖質が存在してい る. 細胞膜の糖蛋白は細胞相互の識別や揬着, 融合に働くとともに抗原認識その他の免疫学的 特異性の発現に重要な役割を演じている。例え ば, 赤血球表面の $\mathrm{ABO}$ 型血液型決定物質や 小腸吸収上皮細胞の微䋐毛に見られる糖衣など はその代表的なものといえよう²). 鼻腔副鼻腔 粘膜に抢ける複合糖質は膜表画の糖衣や細胞間 基質のみならず, 繊毛上に存在する粘液層を形 成して生体防御の上でも重要な役制を果してい るといわれている，ところで，生体内の複合糖 質は動物の種や組織器官など部位による善異が ありまたいろいろな病態によって変化するこ とが知られている、レクチンを用いた上気道粘 膜の複合糖質に関する研究のうち, 正常鼻㨽鼻 


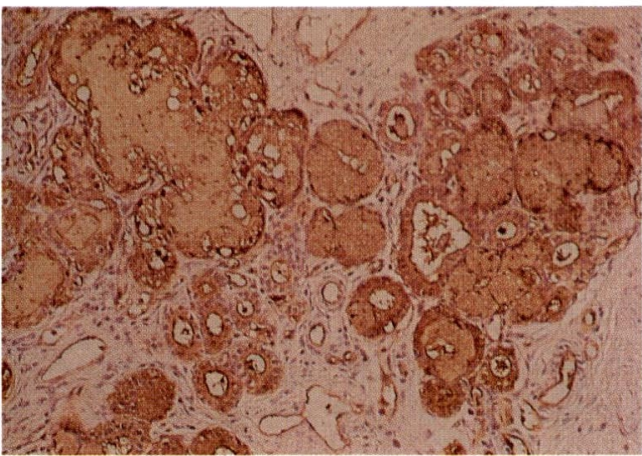

図 I 鼻粘膜上皮下腺組織. UEA- 1 反応. HRP 標識法. 粘液細胞が強く反応している. $\times 100$

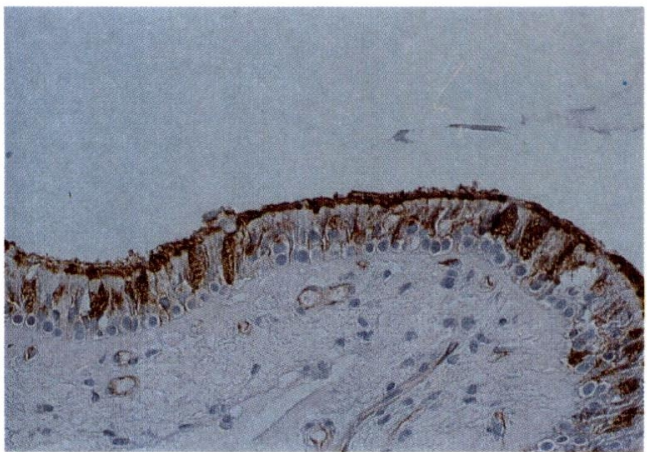

図 3 上顎洞粘膜上皮. UEA- 1 反応. HRP 標 識法. 杯細胞之粘膜表面の粘液がよく反応 している. $\times 200$

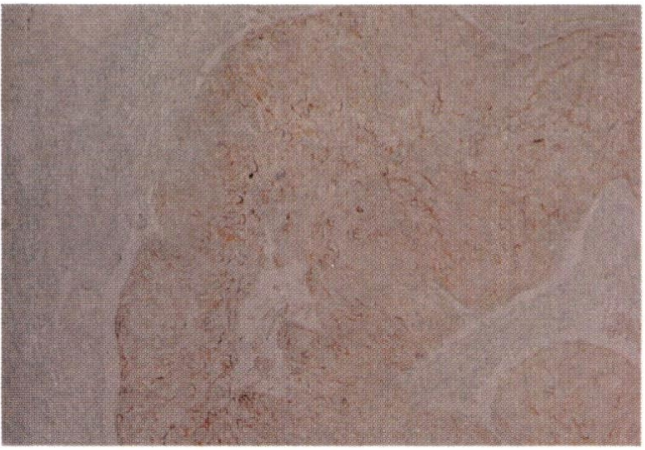

図 5 上顎洞扁平上皮癌 (高分化型).WGA 反 応. HRP 標識法. 癌細胞巣のみに反応を 認める. $\times 40$

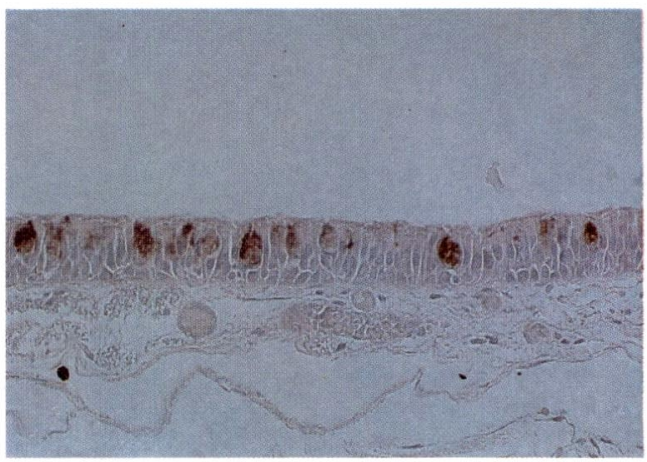

図 2 上頢洞粘膜上皮. PNA 反応. HRP 標識 法。杯細胞のみ反応陽性を認める。 $\times 200$

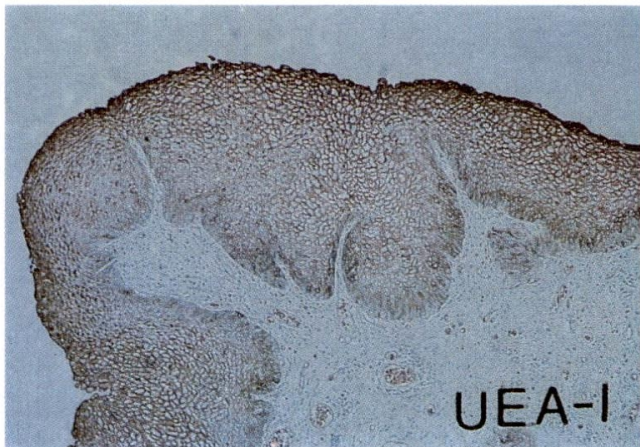

図 4 乳頭腫. UEA- 1 反応. HRP 標識法. 腫 漡外層の細胞膜に高度の反応を梕める. $\times 40$

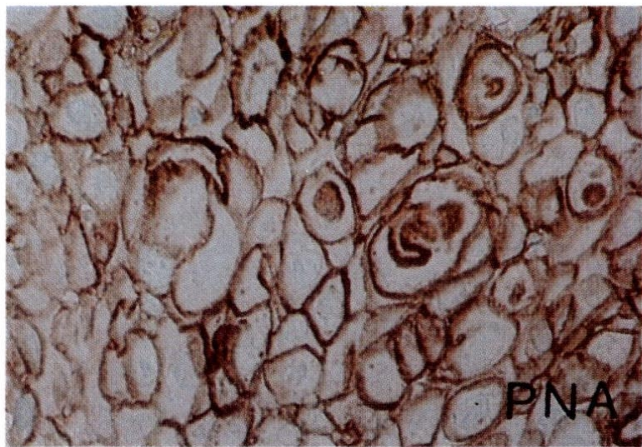

図 6 上顎洞扁平上皮癌(高分化型). PNA 反応. HRP 標識法. 癌細胞の細胞膜, 少数の細胞 質の周辺部および細胞核に高度の反応を示 す. $\times 400$ 
腔, 喉頭, 気管粘膜及び慢性副鼻腔炎, 鼻了 レルギーなどについては既に報告されている $か^{3}{ }^{3778}$, 鼻副鼻腔腫場についての複合糖質の変 化を比較検討した報告はまだまれである。今
回，われわれは 4 種類のレクチンを用い正常の 鼻副鼻胫粘膜の複合糖質の分布を検討し，さら に乳頭腫及び恶性腫湟化に伴って複合糖質がよ゙ のように変化するかを調べ，上皮の前癌病変よ

表 2 鼻副鼻腔粘膜におけるレクチン反応

\begin{tabular}{|c|c|c|c|c|c|c|c|c|}
\hline & \multicolumn{2}{|c|}{ WGA } & \multicolumn{2}{|c|}{ PNA } & \multicolumn{2}{|c|}{ UEA - 1} & \multicolumn{2}{|c|}{$\mathrm{RCA}$} \\
\hline & 下鼻甲介 & 上顎洞 & 下鼻甲介 & 上顎洞 & 下鼻甲介 & 上顎洞 & 下鼻甲介 & 上顎洞 \\
\hline 上皮層 & + & - & - & - & H & - & - & - \\
\hline 基底膜 & - & - & - & - & $H$ & - & - & - \\
\hline 固有層 & - & - & - & - & - & - & + & + \\
\hline 血管内皮 & - & - & - & - & H & $H$ & + & + \\
\hline 粘液細胞 & + & + & + & + & $H$ & + & + & + \\
\hline 漿液細胞 & - & - & - & - & + & + & - & - \\
\hline 杯細胞 & + & + & + & + & + & + & + & + \\
\hline
\end{tabular}

H：高度に染色

+ ：軽度に染色

- : 染色認めず

$1 ：$ 杯細胞を除いた上皮細胞

表 3 舅副鼻腔腫湯におけるレクチン反応

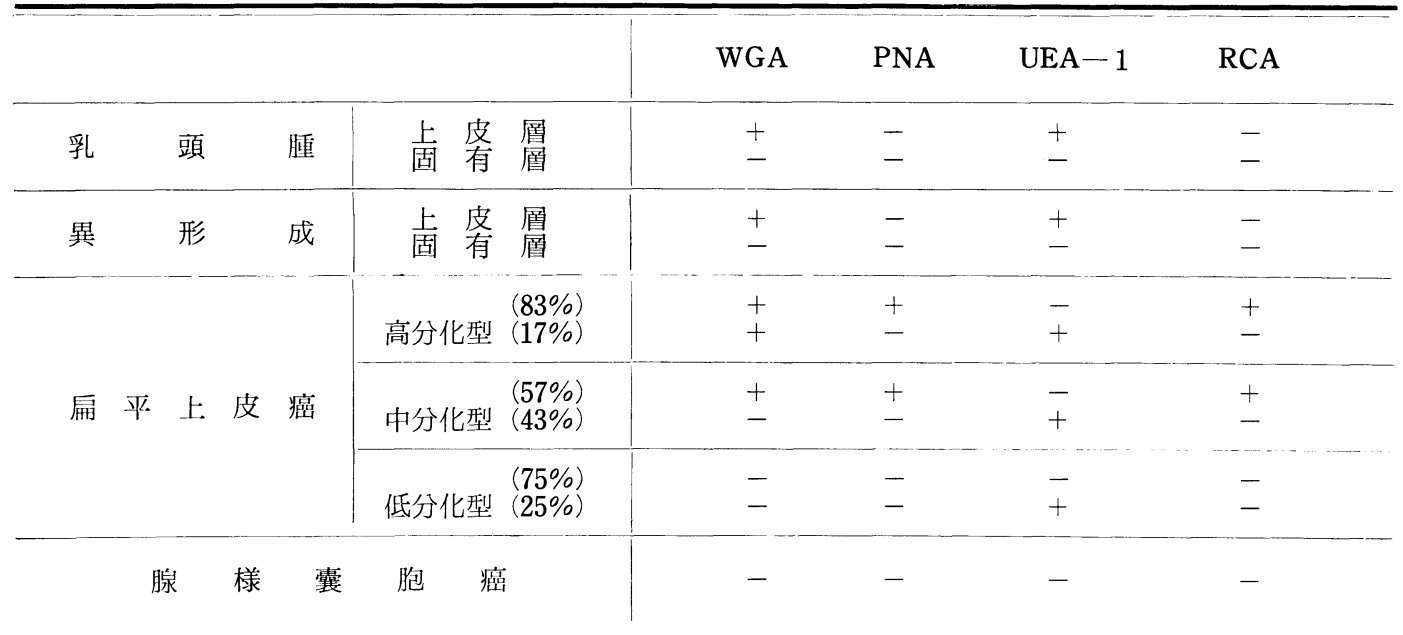

表 4 扁严上皮癌のレクチン反応

\begin{tabular}{c|c|c|c|c}
\hline WGA & PNA & UEA-1 & RCA & 陽 性 率 \\
\hline+ & + & - & + & $9 / 17(52.9 \%)$ \\
+ & - & + & - & $1 / 17(5.9 \%)$ \\
- & - & + & - & $4 / 17(23.5 \%)$ \\
- & - & - & - & $3 / 17(17.7 \%)$ \\
$10 / 17(58.8 \%)$ & $9 / 17(52.9 \%)$ & $5 / 17(29.4 \%)$ & $9 / 17(52.9 \%)$ &
\end{tabular}


り癌化の早期診断にレクチン染色が有用である かの検湖を行った。

複合糖質とは, 糖質 (単糖, 繰り返し二糖, 多糖）と蛋白質や脂質などが結合したものを (うう)。乙れらが含まれる単糖はへキソース (galactose, mannose, glucose), ヘキソサミ ン ( $\mathrm{N}$-acetyl glucosamine, $\mathrm{N}$-acetyl galactosamine), デオキシヘキソース (fucose), シアル酸，ペントースなどがあるてとあよく知 られている4．乙れらの中でわれわれの生体で 重要視されているのは，フコース，ガラクトー ス, $\mathrm{N}$ 一アセチルグルコサミン, $\mathrm{N}$ 一アセチル ガラクトサミン，シアル酸などである ${ }^{5)}$ そこ で，本実験では WGA, PNA, UEA-1, RCA を選んで検討した（表 1 ）.

今回得られた正常鼻副鼻腔粘膜における複合 糖質の研究結果は深水 ${ }^{6)}$ の上気道粘膜における 糖蛋白の組織化学的研究についての報告とはほ 淮一致している，正常では上顎洞粘膜は鼻粘膜 に比し上皮下腺細胞はわずかで杯細胞が比較的 多く認められた。本研究で, UEA-1 と WGA は鼻粘膜の上皮層にびまん性反応を示し, UEA-1 は鼻粘膜の基底膜を他の部位に比較し て強く染色したが，上顎洞粘膜ではこのような 染色性を認めなかった。このととは鼻腔は上気 道の入口部として粘膜_上皮に_七顎洞粘膜上皮よ りフコースとシアル酸が多く含まれて防御的役 割を演じていると考えられた。

一般的に気道に打ける非定型的扁平上皮化生 あるいは異形成などが前癌病変と呼ばれてい る. 頭頸部領域では異形成上皮からなる白斑, 喉頭の異形成上皮などがあげられよう77. 今ま で, 食道上皮の異形成上上皮内癌に関し佐藤 $ら^{8)}$ は軽度之中等度食道上皮の異形成では UEA-1 染色陰性で, 高度異形成では部分的に 基底細胞が UEA-1 染色陽性を示し，上皮内 癌では基底細胞の細胞質に顆粒状あるいはびま ん性反応陽性を認めたと報告している，今回の われわれの実験では，異形成上皮細胞の細胞質 之細胞膜が WGA，UEA-1 反応陽性であり，
これは汪常気道上皮に類似した所見であった。 この結果は異形成上皮は癌紐胞と異なった糖構 造を持つととを示すと思われる。しかし，癌化 した細胞はレクチン結合パターンが後述の如く 異なっていた。

鼻腔乳頭腫についてのレクチンレセプターの 分離の研究では分子量約 15000 以下の成分が Con A，WGA，RCA の各レセプターにおい て多いとの報告9) があった。乳頭腫は再発率が 高く, また組織学的に一部に異型性や核分裂像 が多い ${ }^{10)}$. 時には癌化することああるので乳頭 腫は前癌病変として注意せねばならない。この ような場合癌化の早期診断は極めて重要であ る. 今回の実験では乳頭腫の上皮細胞は細胞膜 のみ WGA と UEA-1 に反応強陽性を示し た。乙れは正常上皮及び後述の悪性腫瘍之も異 なった染色様式である.

悪性腫瘍の分野で, 癌細胞に関する研究は化 学的分析法や免疫学的方法を用いて広範に展開 され，正常細胞に比較していろいろな差異が明 らかにされた．その中でも糖タンパクや糖脂質 などの化学成分の変化が特に注目されるように なった。レクチンによる癌細胞膜構造に関する 研究についての報告は決して少なくないが，耳 鼻咽喉科領域ではまれである，食道癌では上皮 内癌は UEA-1 反志陰性だが, 浸潤癌細胞は UEA-1 反応陽性を示した報告 ${ }^{11)}$ があり，腎 癌組織では clear cell と granular cell とも にWGA, RCA, Con A には陽性反応を, PNA，SBA，DBA には陽性反応を呈する報 告 ${ }^{12)}$ あある。 そのほか青木 ${ }^{13)}$ は子宮体癌では, UEA-1 及び PNA が強い陽性反応を呈し, とくに分化型では反応は増強し, 分化度が低い と染色性は低下すると報告した。このように悪 性腫愓では, 細胞構成成分中複合糖質にも変化 を示すと考えられる. 今回の検索の結果, 鼻副 鼻腔覀性腫瘍には各種レクチンに対する反応性 の多様性があり, 各種癌細胞膜の糖質成分に heterogeneity があるととが示唆された。

扁平上皮癌では分化によって異なった染色性 
を示した。すなわち，高分化型では，WGA， PNA, RCA にて癌細胞膜, 部分的に細胞 質，少数の細胞核が反応したのが $83 \%$ に達し た。中分化型では高分化型と同じ結果を示した もの $(57 \%), U E A-1$ のみ応したもの（43 \%)の二つのパターンを示した。一方, 低分化 型では，いずれのレクチンにも反応陰性だった 屯の $(75 \%)$ が多く，UEA-1 のみ反㐫陽性だ ったのが少数 $(25 \%)$ であった. 腺様囊胞癌で は，いずれのレクチンにあ反応陰性であったて とは極めて興味深い所見である.このことは癌 化する過程で広範囲な生化学的な変化を伴い, 癌細胞の持つ糖鎖のうち, すくなくとも Nacetyl-D-glucosamine, galactose, fucose 含めた糖構造が変化することを示唆している. そのほか, このような癌細胞のレクチン結合 性の差異は細胞の分化程度を反映していると 考えられる，つまり，分化度が高い癌細胞は PNA，WGA，RCA 結合性が高い傾向があ り，その中でも PNA, WGA 反応がより強 い。一方, 分化度が低い癌細胞には UEA-1 反応陽性になる傾向を認めた。今回の結果は PNA が分化途上の細胞之強く結合する性質を 持つ考え ${ }^{14)}$ と一致したが, UEA-1 の反応結果 は異なっていた。

一方, 今回用いた 4 種のレクチンに対して扁 平上皮癌細胞の染色性は表 4 のような反応性が 存在した。この中で WGA, PNA, RCA の 3 種に反応したあのが最も多く $52.9 \%$ あっ た。一方，いろいろのレクチンに対しては WGA が最も高頻度に染色され, 以下はPNA と RCA, UEA-1 の順であった。これがどの ような臨床的意義, 例えば悪性度, 転移性, 放 射線感受性などを持つかは今後の検討課題であ る.

以上より癌細胞では正常上皮細胞と比較して レクチン結合性が異なっていることから, 癌化 に伴う複合糖質，中であ糖質に変化が生じてい ることが推測される。このようにレクチンを用 いて糖銷構造の変化を組織化学的に検討するて
とは癌化の早期診断に極めて有用な手段となり うる可能性がある。さらに，レクチンを利用し た組織化学的㸴究は扁平上皮癌の分化度の決定 やその生物学的態度, さらに臨床病態との関連 性など極めて興味深い問題の解明に有用な手段 になると考えられる。

\section{まとめ}

ヒト正常鼻副鼻腔粘膜と鼻副鼻腔腫瘍につい て複合糖質とその変化を 4 種類の HRP レク チン（WGA，PNA，UEA-1, RCA）により 比較観察した。その結果,

1. 正常鼻粘膜では，上皮層は WGA，UE A-1に対しびまん性に反応し, 鼻副鼻腔粘膜 の杯細胞之腺細胞は WGA, PNA, UEA-1, RCA に対しさまざまな反応を示した.

2. 異形成上皮細胞は細胞質と細胞膜が $\mathrm{W}$ GA，UEA-1 反応陽性であった。

3. 乳頭腫では上皮細胞の細胞膜のみ WG A，UEA-1 反応強陽性であった.

4. 悪性腫瘍では病理組織像と分化度によっ て異なったレクチン染色性を示した。

(1)低分化扁平上皮癌の $75 \%$ はいずれのレクチ ンに対してあ反応しなかった。

(2)中分化型扁平上皮癌では, WGA, PNA, RCA に反応するものと, UEA-1 のみ反応す るあのが約半数づつあった。

(3)高分化型扁平上皮癌では $83 \%$ が WGA, PNA，RCA に反応した.

(4)扁平上皮癌において 4 種のレクチンが染色 される頻度は WGA, PNA と RCA, UEA-1 の順であった。

(5)腺様囊胞癌は全例いずれのレクチンに対し ても反応しなかった。

5. 以上よりレクチン染色は腫瘍マーカーと して癌化の早期診断, 悪性腫瘍の分化度の判定 に有用である可能性があると考察した。

\section{文献}

1) 山口嘉和, 伊藤正高, 斎藤昌三, 他：ヒ卜健常食 道粘膜におけるレクチン結合パターンの組織細胞 
化学的検討. 解剖誌 $60 ： 104 \sim 108,1985$.

2) 高田邦昭, 平野 寛 : 細胞表面電荷の検索, 組織 細胞化学1983. 日本組織細胞化学会編. 133 1 145 頁, 学際企画, 1983.

3) 斎藤 等 : 複合糖質との関係. 耳鼻咽喉科, 頭頸 部外科 MOOK I：44 50, 1986.

4) 井上康男：糖質の化学. 生体分子の化学 1.1 195頁，培風館，東京， 1976.

5 ）村松 喬：細胞表面の糖鎖抗原.耳鼻 29：897 $\sim 903,1983$.

6）深水浩三：上気道粘膜における糖蛋白の組織化学 の研究. 日耳鼻 $88: 449 \sim 454,1985$.

7 ）下里幸雄：頭頸部腫焬の病理. 臨床耳鼻咽喉科. 頭頸部外科全書 8-A (広戸幾一郎, 竹田千里 編).39～61頁，金原出版社，東京， 1985 .

8 ) Sato E, Maruta K, Yonezawa S, et al : Blood group $\mathrm{H}(\mathrm{o})$ antigen in normal, dysplastic and carcinomatous esophageal epithelium. Gann $75: 223 \sim 229,1984$.

9 ）松山博文 : 鼻副鼻腔粘膜の生化学的研究一糖蛋白
を中心に一. 耳鼻臨床 $78: 2849 \sim 2873 ， 1985$.

10) Ridolfi RL, Lieberman $P H$, Erlandson RA, et al : A clinicopathologic study of 30 cases. Am J Surg Pathol I : 43 53, 1977.

11）野上博司, 伊藤正高, 平野 寛: 食道癌. 中外医 薬 $38: 706 \sim 709,1985$.

12）三村晴夫，西山文朗，平野 寬：腎癌，中外医薬 $38: 566 \sim 569,1985$.

13）青木大輔, 野沢志朗, 平野 寛: 子宮体癌. 中外 医薬 $39 ： 436 \sim 439,1986$.

14) Watanabe M, Muramatsu $T$, Shirane $H$, et $a_{1}$ : Discrete distribution of binding sites for dolichos biflorus agglutinin (DBA) and for peanut agglutinin (PNA) in mouse organ tissues. J Histochem Cytochem 29:779 $790,1981$.

原稿採択：昭和 62 年 2 月 5 日 別刷請求先：金 春順

干514 三重県津市江戸橋 2-174

三重大学医学部耳鼻咽喉科学教室) 